\title{
PERFORMA DAN EMISI MESIN EMPAT LANGKAH BERBAHAN BAKAR CAMPURAN BIOETHANOL DAN PERTALITE DENGAN VARIASI TIMING IGNITION
}

\author{
Ayuk Rima Dhani ${ }^{1}$, Farid Majedi ${ }^{2}$ \\ 1,2Politeknik Negeri Madiun \\ Email: ${ }^{1}$ ayukrima14@gmail.com, ${ }^{2}$ farid@pnm.ac.id
}

\begin{abstract}
Abstrak
Jumlah kendaraan bermotor yang meningkat menyebabkan peningkatan konsumsi bahan bakar dan pencemaran udara. Solusinya dengan memakai campuran bioethanol pada bahan bakar pertalite. Penambahan bioethanol dapat meningkatkan angka oktan sehingga membutuhkan beberapa perubahan pada mesin. Salah satunya dengan memajukan timing ignition. Metode yang digunakan adalah dengan memajukan timing ignition sebesar $21^{\circ} \mathrm{BTDC}$, dan $30^{\circ} \mathrm{BTDC}$ dari kondisi standar yaitu $12^{\circ}$ BTDC. Pengujian dilakukan dengan dyno test untuk mengetahui daya dan torsi. Pengujian emisi gas buang menggunakan alat gas analyzer. Berdasarkan hasil pengujian, penambahan bioethanol dapat meningkatkan daya, torsi, serta dapat menurunkan emisi gas buang. Daya tertinggi dicapai oleh variasi timing ignition $30^{\circ}$ BTDC dengan E10 yaitu sebesar $6,7 \mathrm{Hp}$ pada putaran mesin $6750 \mathrm{rpm}$. Torsi tertinggi dicapai oleh variasi timing ignition $30^{\circ} \mathrm{BTDC}$ dengan E10 sebesar $9 \mathrm{Nm}$ pada putaran mesin $4000 \mathrm{rpm}$. Emisi gas buang, konsentrasi CO rata-rata terbaik dicapai oleh variasi timing ignition $21^{\circ}$ BTDC dengan E10 sebesar $0,2 \%$. Konsentrasi $\mathrm{HC}$ terendah pada variasi timing ignition $30^{\circ} \mathrm{BTDC}$ dengan E10 sebesar $74 \mathrm{ppm}$. Nilai rata-rata konsentrasi $\mathrm{CO}_{2}$ tertinggi pada timing ignition $30^{\circ} \mathrm{BTDC}$ dengan E10 sebesar $13,6 \%$. Konsentrasi $\mathrm{O}_{2}$ terendah pada variasi timing ignition $30^{\circ} \mathrm{BTDC}$ dengan E10 sebesar 3\% pada putaran mesin $7000 \mathrm{rpm}$.
\end{abstract}

Kata Kunci: timing ignition, daya, torsi, emisi gas buang

\begin{abstract}
The increasing number of motorized vehicles has led to increased fuel consumption and air pollution. The solution is to use a bioethanol mixture on pertalite fuel. The addition of bioethanol can increase octane numbers so that it requires some changes to the engine. One of them is by advancing timing ignition. The method used is to advance the timing ignition at $21^{\circ}$ BTDC, and $30^{\circ}$ BTDC from the standard condition of $12{ }^{\circ}$ BTDC. Testing is done with dyno test to determine power and torque. Exhaust gas testing uses a gas analyzer. Based on the results of testing, the addition of bioethanol can increase power, torque, and can reduce exhaust emissions. The highest power is achieved by variations of the timing ignition $30^{\circ}$ BTDC with E10 which is $6.7 \mathrm{hp}$ at $6750 \mathrm{rpm}$. The highest torque is achieved by variations of the timing ignition $30^{\circ}$ BTDC with E10 of $9 \mathrm{Nm}$ at $4000 \mathrm{rpm}$ engine speed. Exhaust gas emissions, the best average CO concentration is achieved by variations of the timing ignition $21{ }^{\circ}$ BTDC with E10 by 0,2\%. The lowest HC concentration in the variation of timing ignition $30^{\circ} \mathrm{BTDC}$ with E10 is $74 \mathrm{ppm}$. The highest average CO2 concentration at the timing ignition $30^{\circ} \mathrm{BTDC}$ with E10 is $13.6 \%$. The lowest O2 concentration in timing variations ignition $30^{\circ}$ BTDC with E10 at $3 \%$ at 7000 rpm engine speed.
\end{abstract}

Keywords: ignition time, power, torque, exhaust emissions 


\section{PENDAHULUAN}

Perkembangan teknologi otomotif semakin tahun semakin mengalami peningkatan. Perkembangan teknologi tersebut membawa dampak terjadinya peningkatan jumlah polusi udara dan peningkatan kebutuhan bahan bakar (Gurnito dkk, 2016) Bahan bakar pertalite yang berasal dari minyak bumi adalah bahan bahan bakar yang tidak dapat diperbaharui, sehingga dengan kebutuhan bahan bakar yang meningkat mengakibatkan terjadinya krisis energi bahan bakar (Farid dkk, 2017). Untuk mengurangi penggunaan bahan bakar pertalite adalah dengan cara mengurangi pemakaian pertalite dengan cara mencampur dengan bioetanol. Keuntungan dari pencampuran ini adalah bahwa ethanol cenderung akan menaikkan bilangan oktan dan mengurangi emisi $\mathrm{CO}_{2}$ [Sri Utami, 2007]. Torsi mesin yang dihasilkan dengan bahan bakar bio-etanol lebih kecil daripada bahan bakar pertalite. Hal ini disebabkan Nilai Lower Heating Value $(L H V)$ etanol lebih rendah jika dibandingkan dengan bensin (Farid dkk, 2018).

Dengan variasi Ignition Timing Mapping $\left(10^{\circ}\right.$, $13^{\circ}, 16^{\circ}, \quad 19^{\circ}$, dan $\left.21^{\circ} \mathrm{BTDC}\right)$ menghasilkan kenaikan rata - rata torsi, daya, dan bmep sebesar $6.393 \%$ relatif terhadap pengapian standar, efisiensi termal mengalami kenaikan sebesar $5.409 \%$, sfc mengalami penurunan rata-rata sebesar $1.97 \%$, serta emisi $\mathrm{CO}$ dan $\mathrm{HC}$ mengalami penurunan, masing masing sebesar $5.405 \%$ dan $7.443 \%$ (Gurnito dkk, 2016),

Atok, 2007 dalam penelitian tentang Ignition mapping dan rasio kompresi bahan bakar campuran E85, didapat kesimpulan Ignition timing terbaik dicapai pada 30 BTDC sedangkan compressio ratio tercapai pada kondisi maksimum, yaitu 10,2:1

Dengan E0, E10, E20, E40 dan E60, ignition timing dan compression ratio dapat meningkatkan torsi pada semua penambahan etanol terjadi pada compression ratio 10:1, penurunan $\mathrm{CO}$ terbesar (32\%) terjadi ada E40 dan compression ratio 9:1 sedangkan penurunan $\mathrm{HC}$ terbesar $(31 \%)$ terjadi pada E60 dan compression ratio 10:1 (Topgul dkk, 2006).

Dari beberapa penelitian sebelumnya maka peneliti tertarik untuk meneliti pengaruh variasi ignition timing terhadap performa dan emisi gas buang motor yang biasa dipakai masyarakat sehingga masyarakat dapat mengurangi pemakaian bahan bakar pertalite. Dalam penelitian ini menggunakan variasi timing ignition standar $\left(12^{\circ}\right.$ BTDC), timing ignition $21^{\circ}$ BTDC, dan timing ignition $30^{\circ}$ BTDC. Tujuan penelitian ini adalah mengetahui pengaruhvariasi ignition timing terhadap performa dan emisi gas buang motor. Hasil yang diharapkan adalah terjadi peningkatan performa dan penurunan emisi gas buang.

\section{METODE}

Penelitian yang dilakukan adalah penelitian eksperimen (experimental research) yang menyelidiki kemungkinan pengaruh variabel Independen (variasi timing ignition) terhadap variasi dependen (Torsi, daya dan emisi gas buang) dalam kelompok eksperimental.

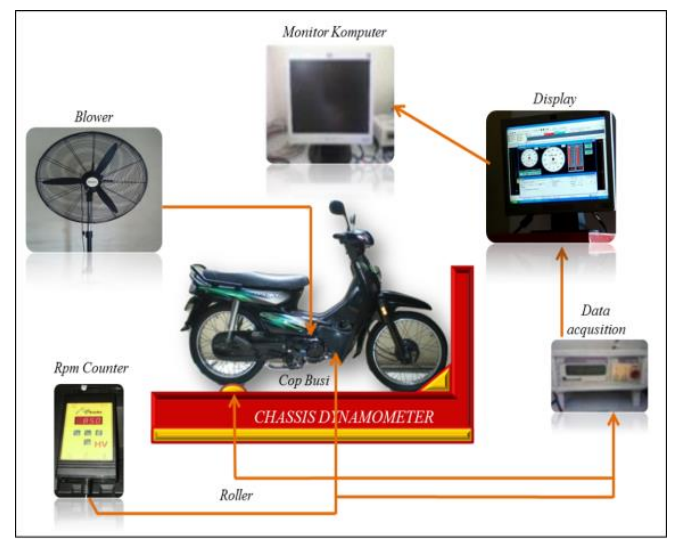

Gambar 1. Rancangan instrumen pengujian daya dan torsi

Penelitian ini dilakukan dengan meelakukan variasi timing ignition standar (12 $\left.{ }^{\circ} \mathrm{BTDC}\right)$, timing ignition $21^{\circ} \mathrm{BTDC}$, dan timing ignition $30^{\circ} \mathrm{BTDC}$. Penelitian dilakukan dengan menguji langsung daya dan torsi dengan menggunakan chasis Dynamometer dengan variasi timing ignition (Gambar 1). Dengan variasi timing ignition yang sama diuji untuk emisi gas buang dengan gas analyzer (Gambar 2).

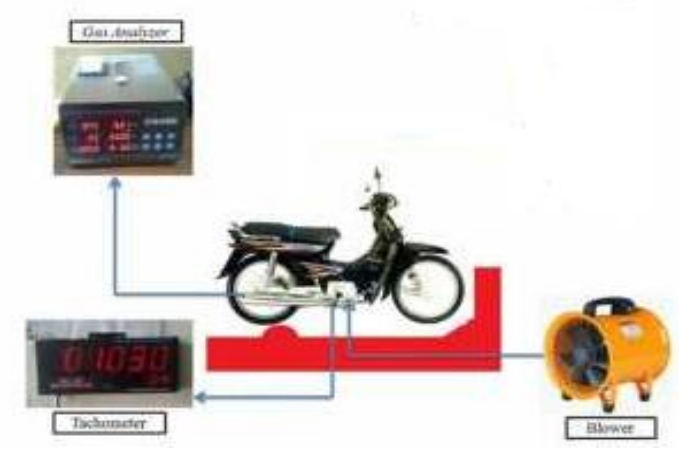

Gambar 2. Rancangan instrumen pengujian analisa gas buang 


\section{HASIL DAN PEMBAHASAN}

Hasil pengujian

Dengan variasi timing ignition standar $\left(12^{\circ}\right.$

BTDC), timing ignition $21^{\circ}$ BTDC, dan timing ignition $30^{\circ}$ BTDC di set, maka dilakukan pengujian dengan dynamometer untuk mengetahui daya dan torsi. Juga dilakukan pengujian emisi gas buang dengan gas analyzer. Dari pengujian tersebut memperoleh data-data sebagai berikut:

\begin{tabular}{|c|c|c|c|c|}
\hline \multicolumn{5}{|c|}{ Tabel I.Hasil Pengujian Daya } \\
\hline $\begin{array}{l}\text { RPM } \\
\text { Daya }\end{array}$ & $\begin{array}{c}\text { STD } \\
\text { Pertalite } \\
\text { (Hp) }\end{array}$ & $\begin{array}{c}\text { STDE10 } \\
\text { (Hp) }\end{array}$ & $\begin{array}{c}\text { 21 }^{\circ} \\
\text { BTDC }^{2} \\
\text { E10 } \\
\text { (Hp) }\end{array}$ & $\begin{array}{c}\text { 30 }^{\circ} \\
\text { BTDC } \\
\text { E10 } \\
\text { (Hp) }\end{array}$ \\
\hline 4000 & 4,3 & 4,6 & 5,3 & 5,3 \\
\hline 4250 & 4,1 & 4,1 & 5,2 & 5,3 \\
\hline 4500 & 4,1 & 4 & 5,2 & 5,3 \\
\hline 4750 & 4,4 & 4 & 5,5 & 5,6 \\
\hline 5000 & 4,4 & 3,8 & 5,4 & 5,8 \\
\hline 5250 & 4,5 & 3,7 & 5,8 & 5,8 \\
\hline 5500 & 4,8 & 4 & 5,6 & 5,3 \\
\hline 5750 & 4,8 & 4 & 6 & 5,7 \\
\hline 6000 & 4,7 & 3,7 & 5,7 & 6 \\
\hline 6250 & 4,7 & 3,7 & 6,2 & 6,3 \\
\hline 6500 & 4,6 & 3,8 & 6,4 & 6,5 \\
\hline 6750 & 4,5 & 3,7 & 6,5 & 6,7 \\
\hline 7000 & 4,2 & 3,3 & 5,6 & 6,6 \\
\hline 7250 & 4,3 & 2,1 & 5,7 & 6,3 \\
\hline 7500 & 3,9 & 1,9 & 5,4 & 5,8 \\
\hline 7750 & 4 & 1,5 & 5,4 & 5,7 \\
\hline 8000 & 3,8 & 0,9 & 5,3 & 6 \\
\hline
\end{tabular}

\section{Hasil Pengujian Torsi}

Tabel II.Hasil Pengujian Torsi

\begin{tabular}{ccccc}
\hline $\begin{array}{c}\text { RPM } \\
\text { Torsi }\end{array}$ & $\begin{array}{c}\text { STD } \\
\text { Pertalite } \\
(\mathbf{N m})\end{array}$ & $\begin{array}{c}\text { STD } \\
\text { E10 } \\
(\mathbf{N m})\end{array}$ & $\begin{array}{c}\mathbf{2 1}^{\circ} \\
\mathbf{B T D C}_{\mathbf{E 1 0}} \\
\mathbf{( N m )}\end{array}$ & $\begin{array}{c}\mathbf{3 0}^{\circ} \\
\mathbf{B T D C}^{\mathbf{E 1 0}} \\
\mathbf{( N m )}\end{array}$ \\
\hline 4000 & 7,4 & 7,7 & 8,9 & 9 \\
4250 & 6,9 & 7,7 & 8,7 & 8,7 \\
4500 & 6,6 & 7,3 & 8,2 & 8,3 \\
4750 & 6,6 & 6,4 & 8,3 & 8,2 \\
5000 & 6,3 & 6,2 & 7,4 & 8,2 \\
5250 & 6,1 & 5,7 & 7,8 & 7,7 \\
5500 & 6 & 5 & 7 & 6,8 \\
5750 & 6,1 & 5,2 & 7,2 & 6,9 \\
6000 & 5,7 & 5 & 6,8 & 6,9 \\
6250 & 5,4 & 4,7 & 6,9 & 7 \\
6500 & 5,2 & 4,3 & 7,1 & 7 \\
6750 & 4,9 & 4,2 & 6,9 & 6,8 \\
7000 & 4,5 & 4,1 & 5,8 & 6,6 \\
7250 & 4,3 & 3,4 & 5,8 & 6 \\
\hline
\end{tabular}

\begin{tabular}{ccccc}
\hline 7500 & 3,8 & 2,2 & 5,3 & 5,7 \\
7750 & 3,6 & 2 & 5 & 5,4 \\
8000 & 3,6 & 1,4 & 4,5 & 5,4 \\
\hline
\end{tabular}

Tabel III Hasil Pengujian Emisi Das Buag Karbon Monoksida

\begin{tabular}{ccccc}
\hline $\begin{array}{c}\text { RPM } \\
(\mathbf{C O})\end{array}$ & $\begin{array}{c}\text { STD } \\
\text { Pertalite } \\
(\boldsymbol{\%})\end{array}$ & $\begin{array}{c}\text { STD } \\
\mathbf{E 1 0} \\
(\boldsymbol{\%})\end{array}$ & $\begin{array}{c}\mathbf{2 1}^{\circ} \text { BTDC } \\
\text { E10 }(\boldsymbol{\%})\end{array}$ & $\begin{array}{c}\mathbf{3 0}^{\circ} \\
\mathbf{B T D C}^{\mathbf{E} 10} \\
\mathbf{( \% )}\end{array}$ \\
\hline 4000 & 0,1 & 0,2 & 0,2 & 4,4 \\
5000 & 0,1 & 0,1 & 0,2 & 4,9 \\
6000 & 0,1 & 0,1 & 0,2 & 5,3 \\
7000 & 0,1 & 0,1 & 0,2 & 4,4 \\
8000 & 0,1 & 0,1 & 0,2 & 1 \\
\hline
\end{tabular}

Tabel IV Hasil Pengujian Emisi Gas Buang Hidrokarbon

\begin{tabular}{|c|c|c|c|c|}
\hline $\begin{array}{l}\text { RPM } \\
\text { (HC) }\end{array}$ & $\begin{array}{c}\text { STD } \\
\text { Pertalite } \\
(\mathbf{p p m})\end{array}$ & $\begin{array}{c}\text { STD } \\
\text { E10 } \\
\text { (ppm) }\end{array}$ & $\begin{array}{l}21^{\circ} \text { BTDC } \\
\text { E10 (ppm) }\end{array}$ & $\begin{array}{c}\text { 30 }^{\circ} \\
\text { BTDC } \\
\text { E10 } \\
(\text { ppm) }\end{array}$ \\
\hline 4000 & 212 & 268 & 1248 & 243 \\
\hline 5000 & 353 & 227 & 1264 & 176 \\
\hline 6000 & 235 & 154 & 1287 & 154 \\
\hline 7000 & 192 & 140 & 679 & 123 \\
\hline 8000 & 185 & 139 & 612 & 74 \\
\hline
\end{tabular}

Tabel V Hasil Pengujian Emisi Gas Buang Karbondioksida

\begin{tabular}{|c|c|c|c|c|}
\hline $\begin{array}{c}\mathbf{R P M} \\
\left(\mathrm{CO}_{2}\right)\end{array}$ & $\begin{array}{c}\text { STD } \\
\text { Pertalit } \\
\text { e }(\%)\end{array}$ & $\begin{array}{l}\text { STD } \\
\text { E10 } \\
(\%)\end{array}$ & $\begin{array}{c}2^{\circ} \\
\text { BTDC } \\
\operatorname{E10}(\%)\end{array}$ & $\begin{array}{c}30^{\circ} \\
\text { BTDC } \\
\text { E10 }(\%)\end{array}$ \\
\hline 4000 & 11 & 11 & 7 & 13 \\
\hline 5000 & 10 & 11 & 16 & 13 \\
\hline 6000 & 11 & 12 & 7 & 13 \\
\hline 7000 & 12 & 13 & 11 & 14 \\
\hline 8000 & 11 & 13 & 8 & 15 \\
\hline
\end{tabular}

Tabel VI Hasil Pengujian Emisi Gas Buang Oksigen

\begin{tabular}{ccccc}
\hline $\begin{array}{c}\text { RPM } \\
\left(\mathbf{O}_{2}\right)\end{array}$ & $\begin{array}{c}\text { STD } \\
\text { Pertalit } \\
\text { e (\%) }\end{array}$ & $\begin{array}{c}\text { STD } \\
\text { E10 } \\
(\%)\end{array}$ & $\begin{array}{c}\mathbf{2 1}^{\circ} \\
\mathbf{B T D C}^{\circ} \\
\mathbf{E 1 0} \\
(\boldsymbol{\%})\end{array}$ & $\begin{array}{c}\mathbf{3 0}^{\circ} \\
\text { BTDC }^{\mathbf{E} 10} \\
(\boldsymbol{\%})\end{array}$ \\
\hline 4000 & 9 & 10 & 16 & 5 \\
5000 & 11 & 8 & 16 & 4 \\
6000 & 8 & 8 & 16 & 4 \\
7000 & 7 & 7 & 11 & 3 \\
8000 & 8 & 7 & 7 & 4 \\
\hline
\end{tabular}




\section{Pembahasan}

Analisa Pengaruh Putaran Mesin Terhadap Daya Dengan Variasi Timing Ignition

Dari Gambar 3 mengenai grafik hubungan daya terhadap putaran mesin daya tertinggi dicapai pada variasi timing ignition $30^{\circ}$ BTDC dengan E10 sebesar 6,7 Hp pada putaran mesin $6750 \mathrm{rpm}$, mengalami kenaikan sebesar $40 \%$ dibandingkan dengan timing ignition standar berbahan bakar pertalite. Pada timing ignition standar dengan bahan bakar pertalite daya tertinggi yang dicapai sebesar 4,8 Hp pada putaran mesin $5500 \mathrm{rpm}$ dan $5750 \mathrm{rpm}$. Pada variasi timing ignition $21^{\circ}$ BTDC dengan E10 daya tertinggi yang dihasilkan sebesar $6,5 \mathrm{Hp}$ pada putaran mesin $6750 \mathrm{rpm}$, mengalami kenaikan sebesar $44 \%$ dibandingkan timing ignition standar berbahan bakar E10 dan mengalami kenaikan 35\% dibanding timing ignition standar pertalite. Sedangkan pada timing ignition $30^{\circ}$ dengan bahan bakar E10 daya tertinggi yang dicapai sebesar 6,7 Hp pada putaran mesin 6750 rpm. Bisatya dkk, 2014 melakukan penelitian tentang performa mesin dengan variasi sudut pengapian, didapat kesimpulan dengan timing ignition lebih tinggi maka daya juga tinggi.

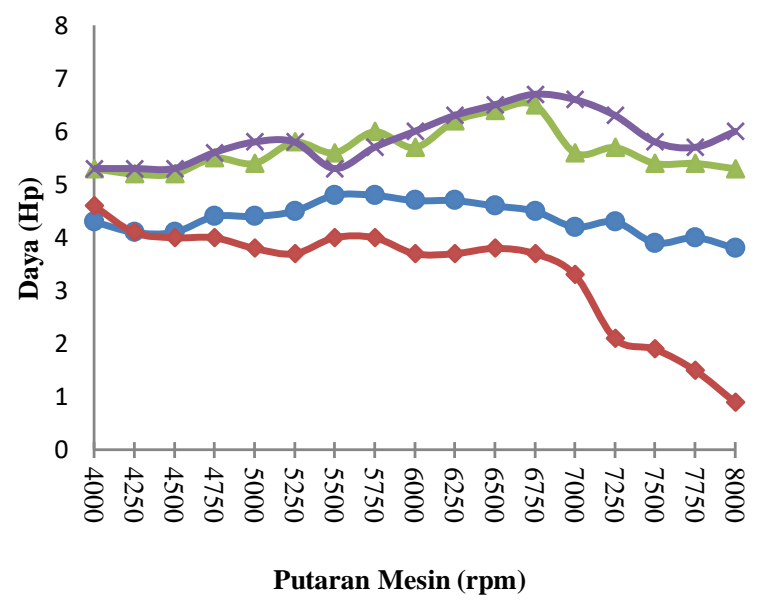

Gambar 3. Grafik Hubungan Daya Terhadap Putaran Mesin

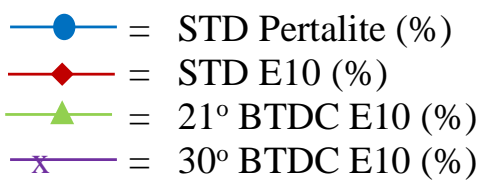

Analisa Pengaruh Putaran Mesin Terhadap Torsi Dengan Variasi Timing Ignition

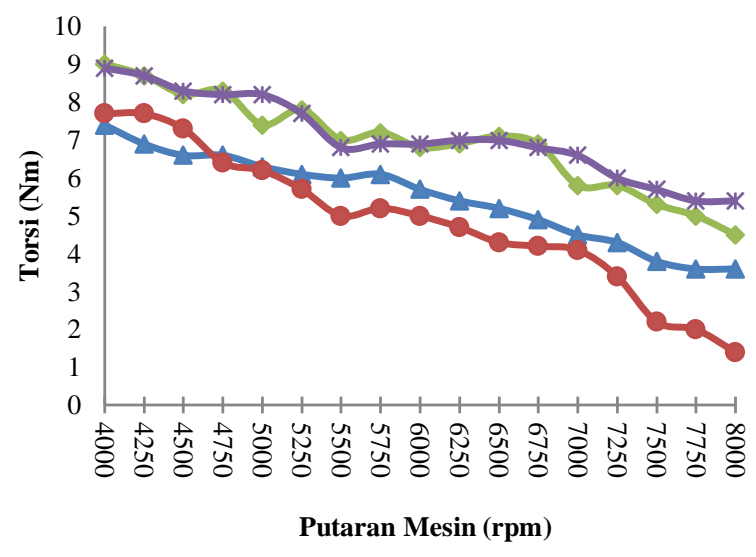

Gambar 4. Grafik hubungan torsi terhadap putaran mesin

$$
\begin{aligned}
\square & =\text { STD Pertalite }(\%) \\
\square & =\text { STD E10 }(\%) \\
\square & =21^{\circ} \text { BTDC E10 }(\%) \\
x & =30^{\circ} \text { BTDC E10 }(\%)
\end{aligned}
$$

Pada Gambar 4 dapat terlihat bahwa torsi tertinggi dicapai pada variasi timing ignition $30^{\circ}$ BTDC dengan E10 sebesar $9 \mathrm{Nm}$ pada putaran mesin $4000 \mathrm{rpm}$, mengalami kenaikan $22 \%$ dari timing ignition standar berbahan bakar pertalite, dan mengalami kenaikan $1 \%$ dibanding dengan variasi timing ignition $21^{\circ} \mathrm{BTDC}$ dengan E10. Pada variasi timing ignition $21^{\circ} \mathrm{BTDC}$ dengan E10 torsi tertinggi yang dihasilkan sebesar $8,9 \mathrm{Nm}$, mengalami kenaikan sebesar $20 \%$ dibanding dengan timing ignition standar pertalite. Pada timing ignition standar berbahan bakar pertalite torsi tertinggi yang dicapai sebesar 7,4 Nm, sedangkan timing ignition standar dengan bahan bakar E10 sebesar 7,7 Nm mengalami kenaikan $4 \%$ dari timing ignition standart berbahan bakar pertalite. Dengan E10 mempunyai nilai torsi lebih tinggi dengan bahan bakar pertalite murni

Analisa Pengaruh Putaran Mesin Terhadap Emisi Gas Buang Dengan Variasi Timing Ignition

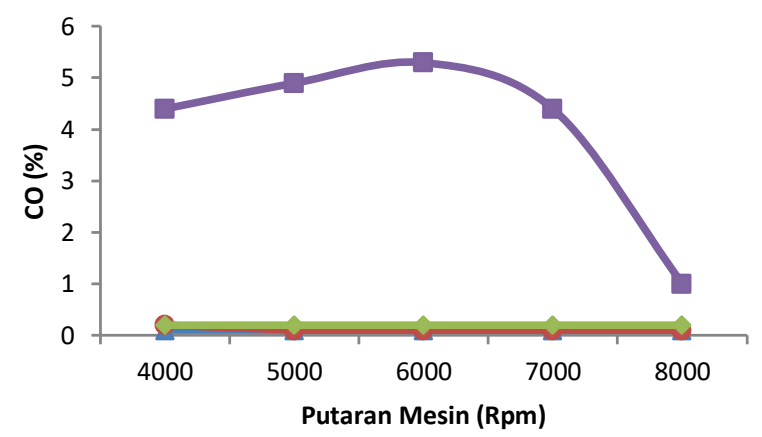

Gambar 5. Grafik Hubungan CO terhadap Putaran Mesin 


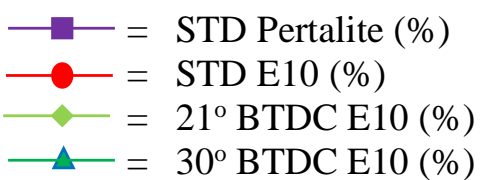

Pada Gambar 5 grafik hubungan CO terhadap putaran mesin pada masing-masing variasi bahan bakar dan timing ignition. Nilai rata-rata yang diperoleh $\mathrm{CO}$ hampir stabil yaitu sebesar $0,1 \%$ pada putaran $4000 \mathrm{rpm}$ hingga $8000 \mathrm{rpm}$. Konsentrasi CO yang terlalu rendah atau tinggi disebabkan karena AFR yang tidak sesuai dengan kebutuhan mesin. Berbeda dengan variasi timing ignition $30^{\circ}$ BTDC dengan E10 nilai rata-rata $\mathrm{CO}$ pada masing-masing putaran mesin sebesar 4\%. Nababan, dkk, 2013 dalam penelitian tentang performa mesin berbahan bakar bensin dan etanol, didapat kesimpulan kadar karbon monoksida pada 4340 rpm sebesar $0,647 \%$. Jadi yang masuk kriteria adalah dengan timing ignition $21^{\circ}$ BTDC dengan E10. Ambang batas konsentrasi $\mathrm{CO}$ menurut Kementrian Lingkungan Hidup pada mesin 4 langkah tahun kendaraan $<2010$ adalah sebesar 5\% (KLH, 2006).

Pada Gambar 6 diketahui bahwa konsentrasi HC tertinggi dihasilkan oleh timing ignition $21^{\circ}$ BTDC dengan E10 sebesar 1287 ppm pada putaran mesin $6000 \mathrm{rpm}$. Sedangkan konsentrasi HC terendah dihasilkan pada variasi timing ignition $30^{\circ} \mathrm{BTDC}$ sebesar $74 \mathrm{ppm}$ pada putaran mesin $8000 \mathrm{rpm}$ atau mengalami penurunan $40 \%$ dibanding standar timing ignition dengan pertalite. Semakin rendah nilai HC maka semakin baik pula emisi gas buang yang dihasilkan. Konsentrasi HC yang terlalu tinggi membuktikan bahwa banyak bahan bakar yang tidak terbakar. Ambang batas konsentrasi HC menurut Kementrian Lingkungan Hidup (2006), pada mesin 4 langkah tahun kendaraan <2010 adalah sebesar 2400 ppm.

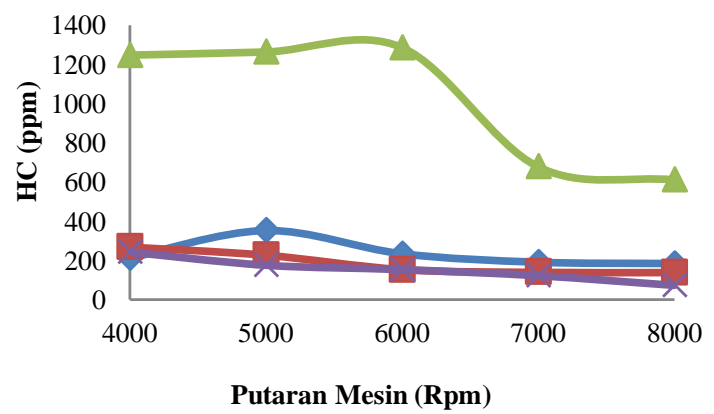

Gambar 6. Grafik hubungan HC terhadap Putaran

Mesin

$\begin{aligned} \longrightarrow & =\text { STD Pertalite }(\%) \\ \square & =\operatorname{STD} \text { E10 }(\%)\end{aligned}$

\section{$\longrightarrow-=21^{\circ} \mathrm{BTDC}$ E10 $(\%)$ \\ $\longrightarrow \mathrm{x}=30^{\circ} \mathrm{BTDC}$ E10 $(\%)$}

Pada Gambar 7 diketahui bahwa konsentrasi $\mathrm{CO}_{2}$ terendah pada variasi timing ignition $21^{\circ} \mathrm{BTDC}$ E10 rata-rata sebesar 9,8\%. Sedangkan konsentrasi $\mathrm{CO}_{2}$ tertinggi pada variasi timing ignition $30^{\circ}$ BTDCE10 rata-rata sebesar $13,6 \%$. Pada timing ignition standar pertalite konsentrasi $\mathrm{CO}_{2}$ sebesar $11 \%$ dan rata-rata timing ignition standar dengan E10 sebesar $12 \%$.

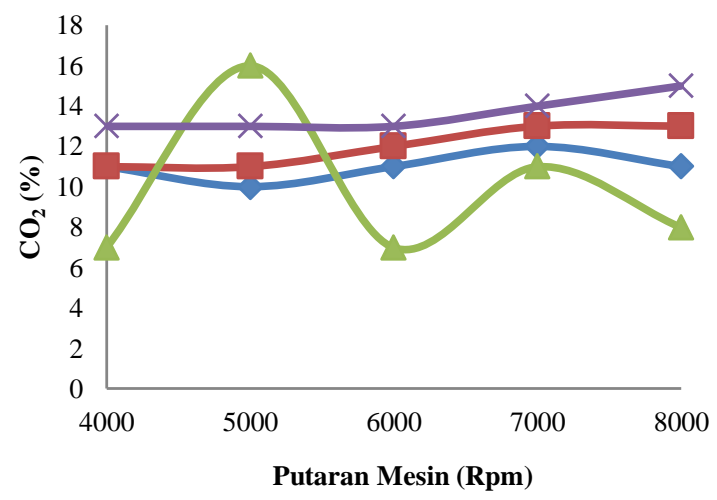

Gambar 7. Grafik hubungan $\mathrm{CO}_{2}$ terhadap Putaran Mesin

$$
\begin{aligned}
\square & =\text { STD Pertalite }(\%) \\
\square- & =\text { STD E10 }(\%) \\
\square- & =21^{\circ} \text { BTDC E10 }(\%) \\
x & =30^{\circ} \text { BTDC E10 }(\%)
\end{aligned}
$$

Berdasarkan gambar 8 diketahui bahwa konsentrasi $\mathrm{O}_{2}$ terendah dihasilkan oleh variasi timing ignition $30^{\circ}$ BTDC dengan E10 sebesar 3\% pada putaran mesin $7000 \mathrm{rpm}$. Pada timing ignition standar pertalite dan E10 diperoleh konsentrasi $\mathrm{O}_{2}$ yang sama, terendah sebesar $7 \%$ pada putaran mesin $7000 \mathrm{rpm}$. Pada timing ignition $21^{\circ} \mathrm{BTDC}$ dengan E10 konsentrasi $\mathrm{O}_{2}$ terendah yang dihasilkan sebesar 7\% pada putaran mesin $8000 \mathrm{rpm}$. Dimana nilai konsentrasi $\mathrm{O}_{2}$ pada emisi gas buang berbanding terbalik dengan $\mathrm{CO}_{2}$, semakin rendah nilai $\mathrm{O}_{2}$ maka semakin baik pula emisi gas buang yang dihasilkan. Konsentrasi $\mathrm{O}_{2}$ yang terlalu tinggi membuktikan bahwa terdapat kegagalan saat pengapian dan menyebabkan misfire 


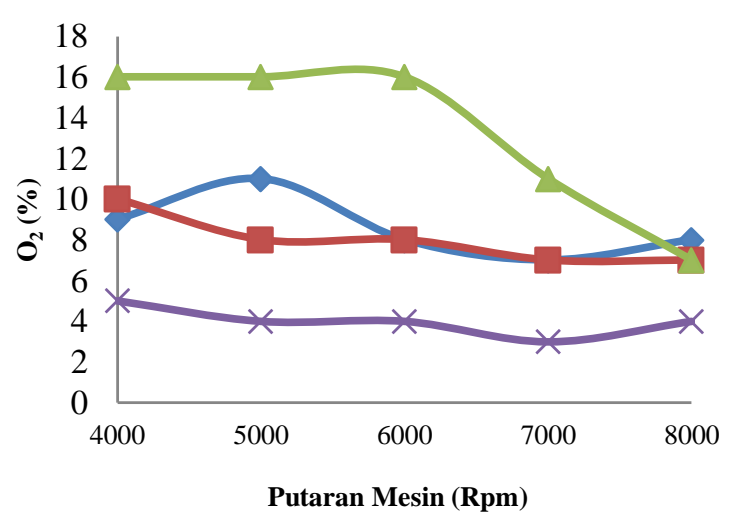
Mesin

Gambar 8 Grafik hubungan $\mathrm{O}_{2}$ terhadap Putaran

$$
\begin{aligned}
\square & =\text { STD Pertalite }(\%) \\
\square & =\text { STD E10 }(\%) \\
\square & =21^{\circ} \text { BTDC E10 }(\%) \\
\square & =30^{\circ} \text { BTDC E10 }(\%)
\end{aligned}
$$

\section{PENUTUP}

\section{Kesimpulan}

Dengan bahan bakar E10 dan variasi timing ignition $30^{\circ}$ mampu menaikkan daya, torsi dibandingkan dengan kondisi standar.

Dengan bahan bakar E10 dan variasi timing ignition $21^{\circ}$ mempunyai kadar $\mathrm{CO}$ terendah dengan kondisi standar

\section{DAFTAR PUSTAKA}

Gurnito, A., Sudarmanta, B., 2016, "Pengaruh Ignition Timing Mapping Terhadap Unjuk Kerja dan Emisi Engine SINJAI 650 CC Berbahan Bakar Pertalite RON 90". Jurnal Teknik ITS. 5 (1), B30-35.

Majedi, F., \& Puspitasari, I., 2017, “Optimasi DayaDan Torsi Pada Motor 4 Tak Dengan Modifikasi Crankshaft Dan Porting Pada Cylinder Head". Jurnal Teknologi Terpadu. 5(1), 82-9.

Majedi, F., Susanto, F., Sandy, B.P., Wiratmoko, B., 2018, "Efek Perubahan Kapasitas Mesin dan Penggunaan 2 Busi pada Motor 4 Langkah terhadap BSFC dan Emisi Gas Buang". Jurnal Teknologi Terpadu, Vol. 6, No. 2, pp. 115120.

Utami, S. H., 2007, "Pemanfaatan Bioethanol Sebagai Bahan Bakar Pengganti Bensin". Gema Teknologi, Vol. 15, No. 2, pp. 99-102

Setiyawan, A., 2007,"Pengaruh Ignition Timing Dan Compression Ratio Terhadap Unjuk Kerja Dan Emisi Gas Buang Motor Bensin Berbahan Bakar Campuran Ethanol 85\% Dan
Premium15\%, ". Seminar Nasional Teknologi, pp. B1 - 9 .

Topgul, T., Huseyin, S. Y., 2006, "The effects of ethanol-unleadegasoline blends and ignition timing on engine performance and exhaust emissions". Journal of Renewable Energy (31), 2534-42, Elsevier.

Irsan B. P., Sutjahjono, H. Zainul M. A., 2014, "Pengaruh Sudut Pengapian Terhadap Unjuk Kerja Motor Bensin 4 LangkahBerbahan Bakar E-10". Hasil Penelitian Mahasiswa ITS.

Nababan, H. M., Ambarita, H., Sitorus, T. B., 2013, "Studi Kinerja Mesin Otto Menggunakan Bahan BakarBensin Dan Etanol 96\%". Jurnal $\boldsymbol{e}$-Dinamis, Vol. 4, No.4, pp. 251-264

Kementerian Lingkungan Hidup. 2006. Peraturan Menteri Negara Lingkungan Hidup Nomor 05 Tahun 2006 tentang Ambang Batas Emisi GasBuangKendaraanBermotorLama.http://la ngitbiru.menlh.go.id/upload/publikasi/pdf/ke pmen_052006.pdf?PHPSESSID $=10977278 \mathrm{c}$ 6012bf9a60a5ff279e44d3a. Diakses pada tanggal 7 Januari 2017. 